\title{
EFISIENSI TATA CARA PENGALOKASIAN, PENYALURAN, PENGGUNAAN, PEMANTAUAN DAN EVALUASI DANA DESA LIKUPANG DUA, KECAMATAN LIKUPANG TIMUR, KABUPATEN MINAHASA UTARA, PROVINSI SULUT
}

\author{
Sayni Armedi ${ }^{1}$, Harijanto Sabijono ${ }^{2}$, Heince R.N. Wokas ${ }^{3}$ \\ ${ }^{1,2,3}$ Jurusan Akuntansi, Fakultas Ekonomi dan Bisnis, Universitas Sam Ratulangi, Jl. Kampus Bahu, Manado, \\ 95115, Indonesia \\ E-mail : sainyzalma@gmail.com
}

\begin{abstract}
This study aims to determine the Efficiency of Procedure of Appropriation, Distribution, Use, Monitoring, and Evaluation of Likupang Dua Village Fund, Kec. Likupang Timur, Kab. North Minahasa, Prov. North Sulawesi if compared with Minister of Finance Regulation no. 49 of 2016. The research design used is descriptive qualitative research. The research informants were the village head, the village secretary, the village administration and the village community of Likupang Dua. The research instrument is self-study assisted by interview guides, recording devices, and observation guidelines. Data collection techniques used were interviews, observation and documentation. Technique examination of data validity using source triangulation technique. The results showed that the implementation of the policy of finance minister no. 49 years 2016 is still not efficient. Inefficiency in the utilization of Likupang Dua village funds are: (1) The procedure of allocation of Likupang Dua Village fund has been efficient with Ministerial Regulation no. 49 of 2016. (2). The Likupang Dua Village Fund Disbursement Procedure is a mismatch due to delays in the disbursement of village funds from RKUN to RKD that is Likupang Dua village due to the delay in submitting the report of the use of fund phase II. (3) Procedures for the use of Likupang Dua Village funds have been streamlined by Minister of Finance's regulation no. 40). (4) The monitoring procedures of Likupang Dua Village funds have been streamlined by Ministerial Regulation no. (5) The procedures for evaluating Likupang Dua village funds have been streamlined by Minister of Finance Regulation no. 49 of 2016.
\end{abstract}

Keywords: Allocation, Distribution, Usage, Monitoring, Evaluation.

\section{PENDAHULUAN}

Anggaran Pendapatan Belanja Desa (APBDes) pada perinsipnya merupakan rencana pendapatan dan pengeluaran desa selama satu tahun kedepan yang dibuat oleh Kepala Desa bersama-sama BPD yang dituangkan kedalam peraturan desa dan sesuai pedoman yang disahkan oleh bupati. Sebagai cerminan kemandirian desa. Undang-Undang Nomor 6 Tahun 2014 tentang Desa yang menyatakan bahwa "Desa adalah desa dan desa adat atau disebut dengan nama lain, selanjutnya disebut Desa adalah kesatuan masyarakat umum yang memiliki tempat dalam mengatur dan mengurus urusan pemerintah, kepentingan masyarakat setempat berdasarkan prakarsa masyarakat, hak asal usul dan/atau hak tradisional yang diakui dan dihormati dalam sistem pemerintahan Negara Kesatuan Republik Indonesia”.

\section{TINJAUAN PUSTAKA}

\subsection{Akuntansi}

Akuntansi adalah proses pencatatan, penggolongan, peringkasan transaksi dan pelaporan informasi ekonomi yang berupa laporan keuangan. Oleh karena itu, pihak yang 
berkepentingan atas perusahaan dapat mengetahui posisi keuangan perusahaan serta hasil operasi pada setiap waktu yang diperlukan.

\subsection{Akuntansi Pemerintahan}

Akuntansi Pemerintahan adalah pencatatan dan pelaporan transaksi-transaksi yang terjadi di badan pemerintah (Hanifah, 2015). Sedangkan menurut Peraturan Pemerintah Republik Indonesia Nomor 71 Tahun 2010 tentang Standar Akuntansi Pemerintahan, akuntansi adalah proses identifikasi, pencatatan, pengukuran, pengklasifikasian, pengikhtisaran transaksi dan kejadian keuangan, penyajian laporan, serta penginterpretasian atas hasilnya.

\subsection{Prinsip Akuntansi}

Di Indonesia ada empat pilar prinsip akuntansi yang diterima secara umum :

1. Strandar Akuntansi Keuangan (SAK-IFRS)

2. SAK-ETAP (Entitas Tanpa Akuntabilitas Publik)

3. Standar Akuntansi Syariah

4. Standar Akuntansi Pemerintahan. (Effendi, $2014: 7$ )

\subsection{Desa}

Desa merupakan salah satu basis dan sumber kegiatan dalam penyelenggaraan pemerintahan dan pembangunan. Desa diharapkan tidak hanya mampu menggerakkan masyarakat untuk berpartisipasi dalam pembangunan, tetapi juga mampu menyelenggarakan pelayanan administrasi desa dengan baik serta dapat mengelola keuangan desa baik dan tertib (Prayudi,2016).

\subsection{Anggaran Pendapatan Dan Belanja Desa (APBDes)}

Dengan adanya APBDes penyelenggaraan pemerintahan desa dapat memiliki sebuah rencana pengelolaan keuangan desa yang terstruktur berdasarkan anggaran yang tersedia dan dana yang dipergunakan (Faridah,2015).

\subsection{Dana Desa}

Dana desa merupakan sumber dana dari APBN yang diberikan kepada Desa dan Desa Adat yang ditransfer melalui anggaran dan pendapatan Belanja Daerah kabupaten/kota dan digunakan untuk membiayai penyelenggaraan pemerintahan, pembangunan, serta pemberdayaan masyarakat, dan kemasyarakatan.

\subsubsection{Pengalokasian}

Pengalokasian dana desa setiap kabupaten / kota

\subsubsection{Penyaluran}

Penyaluran dana desa dilakukan dengan cara pemindahbukuan dari Rekening Kas Umum Negara (RKUN) kepada Rekening Kas Umum Daerah (RKUD), untuk selanjutnya dipindahbukukan dari RKUD ke Rekening Kas Desa (RKD).

\subsubsection{Penggunaan}

Penggunaan dana desa untuk membiayai pembangunan dan pemberdayaan masyarakat yang pelaksanaannya diutamakan secara swakelola dengan menggunakan sumber daya/bahan baku lokal, dan diupayakan dengan lebih banyak menyerap tenaga kerja dari masyarakat Desa setempat.

\subsubsection{Pemantauan Dana Desa}

a. Menatapkan peraturan bupati/walikota mengenai tata cara pembagian dan penetapan Dana Desa setiap Desa;

b. Penyaluran Dana Desa dari RKUD ke RKD;

c. Laporan realisasi penyaluran dan konsolidasi penggunaan Dana Desa; dan

d. Sisa Dana Desa di RKUD.

\subsubsection{Evaluasi Dana Desa}

a. penghitungan pembagian Dana Desa setiap Desa oleh kabupaten/kota; dan

b. Merealisasi penyaluran dan penggunaan Dana Desa. 


\subsection{Efisiensi}

Efisiensi digunakan sebagai bahan untuk mengukur kinerja suatu unit kerja ekonomi.

\section{METODE PENELITIAN}

3.1. Jenis Penelitian

Dalam penelitian ini menggunakan jenis penelitian deskriptif dengan mengumpulkan data-data penelitian yang diperoleh dari Desa Likupang Dua, Kecamatan Likupang Timur, Kabupaten Minahasa Utara, Provinsi SULUT kemudian diuraikan secara rinci untuk mengetahui permasalahan penelitian dan mencari penyelesaiannya.

\subsection{Tempat Dan Waktu Penelitian}

Lokasi penelitian yang diteliti penulis bertempat di Desa Likupang Dua Kecamatan Likupang Timur Kabupaten Minahasa Utara. Waktu penelitian dimulai pada Bulan September tahun 2017.

\subsection{Prosedur Penelitian}

Prosedur yang dilakukan dalam penelitian ini adalah sebagai berikut:

1. Mengidentifikasi masalah

2. Pembatasan masalah

3. Penetapan fokus penelitian

4. Pengumpulan data

5. Pengolahan dan pemaknaan data

6. Pemunculan teori

7. Pelaporan hasil penelitia

\subsection{Metode Pengumpulan Data}

Metode pengumpulan data merupakan teknik atau cara yang dilakukan untuk mrngumpulkan data dan merupakan faktor penting demi keberhasilan penelitian.

\subsubsection{Jenis Data}

Jenis data yang digunakan dalam penelitian ini adalah jenis data kualitatif tentang objek penelitian yaitu berupa laporan keuangan mengenai dana desa yang diterima dari objek penelitian.

\subsubsection{Sumber Data}

Dalam penelitian ini, peneliti menggunakan data primer berupa data diperoleh langsung dari objek penelitian seperti mendapatkan laporan keuangan desa. Sedangkan, data sekunder yang digunakan adalah dari literatur-literatur, buku-buku yang bersangkutan dengan judul penelitian, serta artikel yang dibuat oleh pihak ketiga dan mempunyai relevansi dengan penelitian ini.

\subsubsection{Teknik Pengumpulan Data}

Metode pengumpulan data dalam penelitian ini adalah sebagai berikut :

1. Teknik Observasi

2. Teknik Wawancara

3. Teknik dokumentasi

\subsection{Metode Analisis Data}

Metode analisis data yang digunakan dalam penelitian ini adalah metode deskriptif yaitu yang dimaksud untuk menggambarakan objek yang diteliti dan mengetahui tentang efisiensi tata cara pengalokasian, penyaluran, penggunaan, pemantauan, dan evaluasi dana desa, sehingga bisa ditarik kesimpulan mengenai efisiensi tata cara pengalokasian, penyaluran, penggunaan, pemantauan, dan evaluasi dana Desa Likupang Dua Kecamatan Likupang Timur Kabupaten Minahasa Utara.

Model analisis yang digunakan:

1. Mengidentifikasi efisiensi tata cara pengalokasian, penyaluran, penggunaan, pemantauan, dan evaluasi dana desa melalui wawancara. 
2. Membandingkan hasil dari wawancara dengan data yang ada.

3. Menyajikan data

4. Menarik kesimpulan dari hasil yang disajikan.

5. Memberikan saran

\section{HASIL ANALISIS DAN PEMBAHASAN}

\subsection{Hasil Penelitian}

\subsubsection{Efisiensi Tata Cara Pengalokasian Dana Desa Likupang Dua}

Hasil penelitian yang diperoleh dari Desa Likupang Dua bahwa pengalokasian dana desa di desa Likupang Dua tahun 2017 yaitu tahap I sebesar 60\% dan Tahap II sebesar 40\%. Pengalokasian dihitung dengan memperhatikan jumlah penduduk desa, angka kemiskinan, luas wilayah desa, dan tingkat kesulitan geografis desa Likupang Dua.

\subsubsection{Efisiensi Tata Cara Penyaluran Dana Desa Likupang Dua}

Hasil penelititan yang diperoleh dari Desa Likupang Dua bahwa penyaluran dana desa masih belum efisien karena adanya keterlambatan dalam penyaluran dana desa disebabkan keterlambatan dari RKUD (Rekening Kas Umum Daerah) untuk selanjutnya dipindahbukukan ke RKD (Rekening Kas Desa) dikarenakan keterlambatan dari pihak desa dalam menyelesaikan dan memasukkan laporan realisasi penyaluran dan konsolidasi penggunaan dana desa tahun anggaran sebelumnya yaitu paling lambat minggu kedua sebelum tahapan penyaluran bulan tersebut.

\subsubsection{Efisiensi Tata Cara Penggunaan Dana Desa Likupang Dua}

Penggunaan Dana Desa Likupang Dua sudah sesuai dengan Peraturan Menteri Keuangan Nomor 49 Tahun 2016 yang dianggarkan untuk belanja desa di bidang pembangunan desa yaitu di tahun anggaran 2017 pada tahap I 60\% dengan jumlah anggaran Rp. 465.085. 229 untuk pembiayaan kegiatan : pembangunan drainase dan plat beton penutup jaga IV dan V, pembangunan drainase TPI jaga IV, pembangunan sarana dan prasarana olahraga, pembuatan lampu jalan dan pembiayaan kegiatan pemberdayaan masyarakat desa seperti : Kegiatan Posyandu, Kegiatan Pelatihan Peningkatan Kapasitas Aparatur Pemerintah Desa (Bimtek Aparat Desa dan BPD), Kegiatan Pelatihan PTPKD, TPK dan KPMD/KTD, Kegiatan Pelatihan Kelompok Perempuan (OVOP), Kegiatan Pelatihan Usaha Ekonomi Produktif, Kegiatan Penguatan / Restrukturisasi Pengurus BUMDes, dan Kegiatan Pelatihan Kelompok Nelayan. Penggunaan dana desa pada tahap II 40\% Rp. 310.056.819 yaitu untuk pembiayaan kegiatan pembangunan drainase dan plat beton penutup jaga IV dan $\mathrm{V}$, pembangunan gedung paud $6 \times 9 \mathrm{M}$, dan pembiayaan kegiatan pemberdayaan masyarakat yaitu kegiatan posyandu.

\subsubsection{Efisiensi Tata Cara Pemantauan Dana Desa Likupang Dua}

Pemantauan dana desa Likupang Dua sudah sesuai dengan Peraturan Menteri Keuangan Nomor 49 Tahun 2016 yaitu dipantau oleh pihak pemerintah Badan Pemeriksa Keuangan (BPK), Bupati, dan dipantau oleh masyarakat desa dengan adanya penyampaian informasi oleh peragkat desa kepada masyarakat desa likupang dua tentang laporan dana desa tahap I dan tahap II yang di sampaikan pada setiap pertemuan rukun desa yang di khususkan untuk membahas tentang dana desa likupang dua.

\subsubsection{Efisiensi Tata Cara Evaluasi Dana Desa Likupang Dua}

Laporan realisasi pelaksanaan APBDes yaitu dana desa likupang dua baik tahap I maupun tahap II yang dibuat oleh sekdes dan di setujui oleh hukum tua untuk selanjutnya di berikan oleh kepala desa kepada Bupati setiap akhir tahun anggaran yang terdiri dari pendapatan, belanja dan pembiayaan desa tahap I dan tahap II tahun anggaran 2017. Laporan Realisasi pelaksanaan APBDes diinformasikan kepada masyarakat secara tertulis dengan informasi yang mudah di akses oleh masyarakat: melalui kegiatan kemasyarakatan yaitu kegiatan rukun desa, papan pengumuman, dan media informasi lainnya. Dan untuk sisa dana 
desa di RKD tahun anggaran 2017 dana desa likupang dua tidak memiliki sisa dana desa, namun jika terdapat sisa dana desa maka perangkat desa dalam hal ini Kepala Desa menganggarkan kembali sisa dana desa Likupang Dua dalam rancangan APBDes tahun anggaran berikutnya.

\subsection{Pembahasan}

\subsubsection{Efisiensi Tata Cara Pengalokasian Dana Desa Likupang Dua Dihubungkan} Dengan Kebijakan Menteri Keuangan No. 49 Tahun 2016

Efisiensi pengalokasian APBDesa Likupang Dua mengacu pada peraturan menteri keuangan no. 49 tahun 2016 tentan tata cara pengalokasian, peyaluran, pemantauan, penggunaan dan evaluasi dana desa sudah efisien dengan proses pengalokasian APBDesa Likupang Dua. Pengalokasian dana desa di desa Likupang Dua tahun 2017 yaitu tahap I sebesar $60 \%$ dan Tahap II sebesar 40\%. Pengalokasian dana desa Likupan Dua yang langsung di salurkan ke rekening desa Likupang Dua terbagi menjadi dua tahapan yaitu Tahap I tahun 2017 yaitu 60\%.

\subsubsection{Efisiensi Tata Cara Penyaluran Dana Desa Likupang Dua Dihubungkan Dengan Kebijakan Menteri Keuangan No. 49 Tahun 2016}

Efisiensi penyaluran APBDesa Likupang Dua mengacu pada peraturan menteri keuangan no. 49 tahun 2016 tentan tata cara pengalokasian, peyaluran, pemantauan, penggunaan dan evaluasi dana desa sudah efisien dengan proses penyaluran APBDesa Likupang Dua penyaluran dana desa masih belum efisien karena adanya keterlambatan dalam penyaluran dana desa disebabkan keterlambatan dari RKUD (Rekening Kas Umum Daerah).

\subsubsection{Efisiensi Tata Cara Penggunaan Dana Desa Likupang Dua Dihubungkan Dengan} Peraturan Menteri Keuangan No. 49 Tahun 2016

Efisiensi penggunaan APBDesa Likupang Dua mengacu pada peraturan menteri keuangan no. 49 tahun 2016 tentan tata cara pengalokasian, peyaluran, pemantauan, penggunaan dan evaluasi dana desa sudah efisien dengan proses pemantauan APBDesa Likupang DuaPenggunaan Dana Desa Likupang Dua sudah sesuai dengan Peraturan Menteri Keuangan Nomor 49 Tahun 2016 yang dianggarkan untuk belanja desa di bidang pembangunan desa.

4.3.4 Efisiensi Tata Cara Pemantauan Dana Desa Likupang Dua Dihubungkan Dengan Peraturan Menteri Keuangan No. 49 Tahun 2016

Efisiensi pemantauan APBDesa Likupang Dua mengacu pada peraturan menteri keuangan no. 49 tahun 2016 tentan tata cara pengalokasian, peyaluran, pemantauan, penggunaan dan evaluasi dana desa sudah efisien dengan proses pemantauan APBDesa Likupang DuaPemantauan dana desa Likupang Dua sudah sesuai dengan Peraturan Menteri Keuangan Nomor 49 Tahun 2016 .

\subsubsection{Efisiensi Tata Cara Evaluasi Dana Desa Likupang Dua Dihubungkan Dengan} Peraturan Menteri Keuangan No. 49 Tahun 2016

Efisiensi evaluasi APBDesa Likupang Dua mengacu pada peraturan menteri keuangan no. 49 tahun 2016 tentang tata cara pengalokasian, peyaluran, pemantauan, penggunaan dan evaluasi dana desa sudah efisien dengan proses evaluasi APBDesa Likupang Dua Laporan realisasi pelaksanaan APBDes yaitu dana desa likupang dua baik tahap I maupun tahap II yang dibuat oleh sekdes dan di setujui oleh hukum tua untuk selanjutnya di berikan oleh kepala desa kepada Bupati setiap akhir tahun anggaran yang terdiri dari pendapatan, belanja dan pembiayaan desa tahap I dan tahap II tahun anggaran 2017.

\section{KESIMPULAN DAN SARAN}

\subsection{Kesimpulan}

Berdasarkan pembahasan yang telah disajikan pada bab sebelumnya maka dapat ditarik kesimpulan sebagai berikut: 
1. Tata cara pengalokasian dana desa Likupang Dua tahun anggaran 2017 sudah efektif dan efisien dengan Peraturan Menteri Keuangan No. 49 Tahun 2016.

2. Tata cara penyaluran dana desa Likupang Dua tahun anggaran 2017 tidak efektif dan tidak efisien dengan Peraturan Menteri Keuangan No. 49 Tahun 2016 karena adanya keterlambatan dalam pelaporan draft pengeluran dana desa tahap II.

3. Tata cara penggunaan dana desa Likupang Dua tahun anggaran 2017 sudah efektif dan efisien dengan Peraturan Menteri Keuangan No. 49 Tahun 2016.

4. Tata cara pemantauan dana desa Likupang Dua tahun anggaran 2017 sudah efektif dan efisien dengan Peraturan Menteri Keuangan No. 49 Tahun 2016.

5. Tata cara pengevaluasian dana desa Likupang Dua tahun anggaran 2017 sudah efektif dan efisien dengan Peraturan Menteri Keuangan No. 49 Tahun 2016.

\subsection{Saran}

Berdasarkan kesimpulan diatas peneliti memberikan saran sebagai berikut :

1. Kiranya di tahun 2018 desa Likupang Dua bisa lebih konsisten lagi dalam melaporkan laporan pertanggungjawaban sesuai dengan tahapan yang telah di tentukan sehingga tidak akan terjadi keterlambatan dalam penyaluran dana desa untuk kegiatan desa di tahun berikutnya.

2. Pentingnya sumber daya manusia juga menjadi hal yang perlu diperhatikan, karena SDM yang berkualitas dan kompeten sangat dibutuhkan agar mampu bekerja dengan baik dan menghasilkan kinerja kerja yang bekualitas dalam membantu penataan prosedur penyaluran dana desa dengan efisien sesuai dengan peraturan yang berlaku.

3. Penting adanya kerjasama antara perangkat desa agar tidak saling berharap dalam menjalankan tanggungjawab untuk kepentingan desa Likupang Dua ditahun -tahun berikutnya.

4. Adanya pengawasan langsung dan ketelitian dari hukum tua yang bertanggungjawab penuh terhadap bawahan-bawahannya dalam memanajamen administrasi dana desa Likupang Dua.

5. Untuk peneliti selanjutnya agar dapat melakukan penelitian pada beberapa desa yang lain di Kecamatan Likupang Timur kabupaten Minahasa Utara agar dapat menggambarkan secara umum dan luas tata cara pengalokasian, penyaluran, penggunaan, pemantauan, dan evaluasi dana desa.

\section{DAFTAR PUSTAKA}

Akbar, Lukmanul, Dipo. 2015. "Peran Pemerintahan Desa Dalam Penyusunan APBDes Perspektif Undang-Undang Nomor 6 Tahun 2014 Tentang Desa".

Badriyah, hurriyah. 2015. Buku Pintar Akuntansi Dagang Untuk Orang Awam. Penerbit HB. Benedicto, Dkk. 2013. "The Role Of Accounting In Public Governance Process".

Dewanti, D, W, Elsa,2015. "Analisis Perencanaan Pengelolaan Keuangan Desa di Desa Boreng (Studi Kasus Pada Desa Boreng Kecamatan Lumajang Kabupaten Lumajang)".

Dissanayaka, Dkk. 2015. “The Development Of Public Sector Accounting And Financial Reporting In Sri Lanka”.

Faridah.2015. "Transparansi Dan Akuntabilitas Pemerintah Desa Dalam Pengelolaan Anggaran Pendapatan Dan Belanja Desa (APBDes).

Hanifah, I, Suci, 2015. "Akuntabilitas dan transparansi Pertanggungjawaban Anggaran Pendapatan Dan Belanja Desa (APBDes)".

Iqsan. 2016. "Transparansi Pemerintah Desa Dalam Penyusunan Anggaran Pendapatan dan Belanja Desa (APBDes) Di Desa Long Nah Kecamatan Muara Ancalong Kabupaten Kutai Timur". 
Kadjudju, Delyane. 2017. Analisis Penerapan Permendagri No.113 Tahun 2014 Dalam Perencanaan, Pelaksanaan, Dan Pertanggungjawaban APBDes (Studi Kasus Desa Motandoi dan Desa Motandoi Selatan Kecamatan Pinolosian Timur Kabupaten Bolaang Mongondow Selatan".

Kazimoto, Paluku. 2013. "Analysis Of Village Financial Management Challenges In Arumeru Dostrict In Tanzania"

Mulyadi, 2015. "Pengaruh produktibitas, efisiensi, kepuasan kerja terhadap perputaran karyawan bagian marketing".

Pujiyanti, Ferra,. 2015. Akuntansi Dasar. Penerbit: Lembar Pustaka Indonesia. Tangerang.

Pratiwi, Rianti.2016. "Implementasi Pengelolaan Keuangan Dana Desa Yang Bersumber Dari APBN 2015".

Prayudi, Dkk.2016. Akuntansi Dalam Perspektif Penglolaan Keuangan Desa

Sumpeno, W. 2011.Perencanaan Desa Terpadu.Banda Aceh: Read

Solekhan, M. 2012. Penyelenggaraan Pemerintah Desa Berbasis Partisipasi Masyarakat dalam Membangun Mekanisme Akuntabilitas.Malang: Setara Press.

Sedarmayanti, 2016. "Pengaruh produktibitas, efisiensi, kepuasan kerja terhadap perputaran karyawan bagian marketing".

Widodo, Dkk. 2016. "Sistem Akuntansi Pengelolaan Dana Desa". 